American Journal of Agricultural and Biological Sciences 2 (3): 168-183, 2007

ISSN 1557-4989

(C) 2007 Science Publications

\title{
The Nutritive Value of Wastewater Grown Barley and its Utilization in Fish Feed
}

\author{
A.M. Snow and A.E. Ghaly \\ Department of Process Engineering and Applied Science, Dalhousie University, \\ Halifax, Nova Scotia, Canada B3J 1Z1
}

\begin{abstract}
The feasibility of using wastewater grown barley plants as a component of fish feed was evaluated. The barley plants were grown in a hydroponics system on wastewater from a recirculating aquaculture facility. The effects of wastewater application rate on plant growth and pollution potential reduction were investigated. At the end of the experiment, the average crop heights and yields were 31.0 and $36.0 \mathrm{~cm}$ and 59 and $83 \mathrm{t} \mathrm{ha}^{-1}$ at wastewater application rates of 690 and $1380 \mathrm{~mL}$ compartment $^{-1}$ day $^{-1}$, respectively. The hydroponics system reduced the TS, COD, $\mathrm{NH}_{4}^{+}-\mathrm{N}, \mathrm{NO}_{2}^{-}-\mathrm{N}$, $\mathrm{NO}_{3}{ }^{-} \mathrm{N}$ and $\mathrm{PO}_{4}{ }^{-3}-\mathrm{P}$ of the aquaculture wastewater by 51.5-52.9, 72.3-72.3, 81.8-82.3, 97.9-98.2, 78.979.7 and $84.7-86.3 \%$, respectively. The aquaculture wastewater grown barley met the energy, fat, Ca, $\mathrm{Mg}, \mathrm{P}, \mathrm{Na}, \mathrm{S}$ and $\mathrm{Mn}$ dietary requirements of aquatic animals. It exceeded the carbohydrate, crude fiber, $\mathrm{Cl}, \mathrm{K}, \mathrm{Cu}, \mathrm{Fe}, \mathrm{Se}$ and $\mathrm{Zn}$ dietary requirements of fish and shellfish. It did not contain sufficient amounts of protein. The aquaculture wastewater grown barley could potential be used as a component in fish feed, but will require supplementation with a high protein source that contains low concentrations of carbohydrate, crude fiber, $\mathrm{Cl}, \mathrm{K}, \mathrm{Cu}, \mathrm{Fe}, \mathrm{Se}$ and $\mathrm{Zn}$. Common protein sources that could be used for supplementation included fishmeal, bone meal and blood meal.
\end{abstract}

Key words: Aquaculture, wastewater, hydroponics, barley, fish feed, water quality, nutrition

\section{INTRODUCTION}

Aquaculture, the controlled cultivation and harvest of aquatic organisms, has become the fastest growing food production sector in the world. The industry has grown at an average rate of $8.9 \%$ per year since 1970 , compared with only $1.2 \%$ for capture fisheries and $2.8 \%$ for livestock production systems over the same

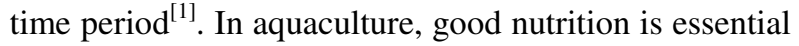
for the production of a healthy, high quality product. Generally, cultured fish do not consume natural prey and forages, but are provided with a manufactured feed formulated to contain a range of essential and nonessential nutrients from a variety of raw ingredients. To sustain the high rates of increase in aquaculture production, an increase in the manufacture of fish feeds is required.

Aquaculture feeds are amongst the most expensive animal feeds and can represent 40 to $50 \%$ of production costs $^{[2]}$. Protein is typically the largest and most expensive component of an aquaculture $\operatorname{diet}^{[3]}$. Due to their high nutritional content, marine protein meals such as fish meal, squid meal and shrimp meal form the basis of the majority of pelleted feeds. Fish meals are generally incorporated into feeds at levels between 30 and $60 \%{ }^{[4]}$. However, marine meals are expensive and may be difficult to obtain on a regular basis. The sustainability of the aquaculture industry depends on the reduction of wild fish inputs into fish feed. As a result, plant meals, which are considerably cheaper than marine meals, are being studied as a partial replacement for marine meals in aquaculture feeds ${ }^{[3,5]}$.

The primary aim of this study was to evaluate the feasibility of using barley plants as a component of fish feed as determined by their nutritive value (energy, carbohydrates, crude protein, crude fat, crude fiber, $\mathrm{Ca}$, $\mathrm{Cl}, \mathrm{Mg}, \mathrm{P}, \mathrm{K}, \mathrm{Na}, \mathrm{S}, \mathrm{B}, \mathrm{Cu}, \mathrm{Fe}, \mathrm{Mn}, \mathrm{Mo}$, Se and Zn). The barley plants used in this study were grown in a hydroponics system on wastewater from a recirculating aquaculture system. The specific objectives of the study were to evaluate: (a) the effect of wastewater

Corresponding Author: A.E. Ghaly, Professor, Department of Process Engineering and Applied Science, Dalhousie University, Halifax, Nova Scotia, Canada; Email: abdel.ghaly@dal.ca; Tel: (902)494-6014; Fax: (902)420-7639 
application rate on plant height and yield, (b) the effectiveness of barley plants in reducing the pollution load of the aquaculture wastewater as measured by TS, $\mathrm{COD}, \mathrm{NH}_{4}{ }^{+}-\mathrm{N}, \mathrm{NO}_{2}^{-}-\mathrm{N}, \mathrm{NO}_{3}^{-}-\mathrm{N}$ and $\mathrm{PO}_{4}^{-3}-\mathrm{P}$ and (c) the nutritional value of the hydroponically grown barley as a fish feed.

\section{EXPERIMENTAL APPARATUS}

The hydroponic system (Fig. 1) consisted of a frame, growth troughs and aeration, lighting, cooling, irrigation, supernatant collection and control units.

The frame (Fig. 2) was constructed of angle iron with a width of $244 \mathrm{~cm}$, a depth of $41 \mathrm{~cm}$ and a height of $283 \mathrm{~cm}$. The back and the top were covered with 0.6 $\mathrm{cm}$ thick plywood sheets. The frame consisted of three shelves (76 cm apart). Each shelf was divided vertically into two cells by dividers made of $1.2 \mathrm{~cm}$ thick plywood sheets. The frame supported the growth troughs and all other systems.

The plant growth unit consisted of six troughs. Each trough was made of galvanized steel and was divided into three compartments. Each compartment held a tray that acted as the plant support medium and consisted of a wire-mesh base ( 16 openings $\mathrm{cm}^{-2}$ ) with $5 \mathrm{~cm}$ high metal sides. The dimensions of each trough and plant supporting tray are shown in Fig. 2. The trays were positioned in the troughs so that the plant roots were in contact with the liquid waste. The placement of trays was maintained by means of supports welded into the corners of each compartment $5 \mathrm{~cm}$ below the top edge of the trough.

An aeration unit was installed in each compartment to provide oxygen to the immersed roots of the growing plants. The main air supply was connected to a manifold (PVC pipe of $2.54 \mathrm{~cm}$ outside diameter) on each shelf using PVC tubing of $0.635 \mathrm{~cm}$ outside diameter. The air flow from the main supply to the manifold on each shelf was controlled by a pressure regulator (Model 129121510, Aro, Brayn, OH). Six aeration units were connected to the manifold on each shelf using PVC tubing of $0.635 \mathrm{~cm}$ outside diameter. Each aerator consisted of a main tube with three perforated stainless steel laterals coming off it at right angles to the main. Each lateral was approximately $30 \mathrm{~cm}$ long whereas the main was $26.5 \mathrm{~cm}$ long.

The lighting unit was designed to provide approximately 360 hectolux of illumination per trough. This was achieved by a mixture of fluorescent and incandescent lamps. Six $34 \mathrm{~W}$ cool white fluorescent

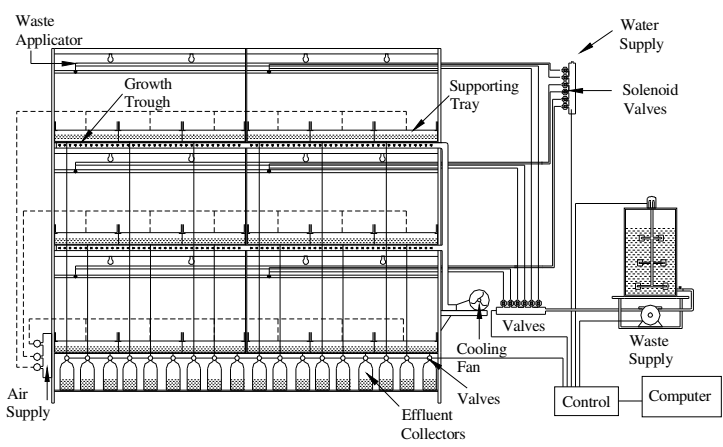

Fig. 1: The hydroponics system

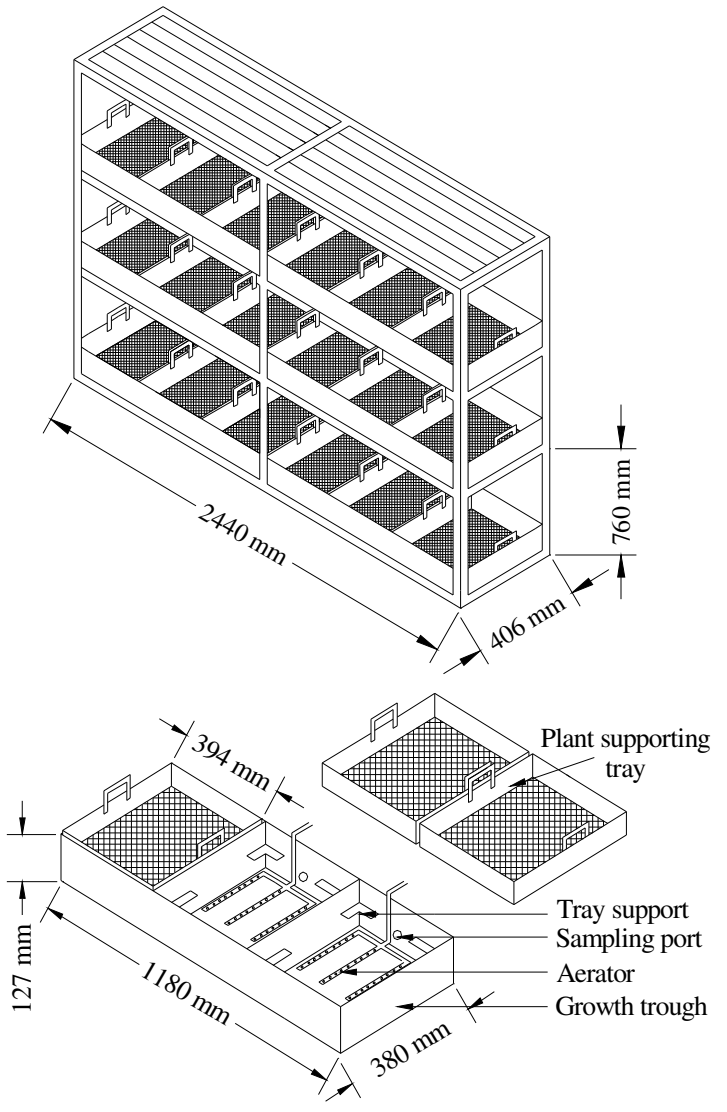

Fig. 2: The frame, growth trough and plant support tray

lamps (122 cm in length) and two $60 \mathrm{~W}$ Plant Gro N Show bulbs were fastened above each trough. A cooling unit was designed to continuously remove the heat produced by the lamps to avoid heating of the wastewater on the upper and middle shelves. For each of these two shelves, a $5 \mathrm{~cm}$ diameter PVC pipe, having $6 \mathrm{~mm}$ diameter holes spaced $6 \mathrm{~cm}$ apart and facing out, was placed under the backside of the troughs. Two metal blocks supported the front side of the trough. This provided a $5 \mathrm{~cm}$ space between the trough and the lighting unit of the shelf below it. A $5 \mathrm{~cm}$ diameter PVC 
pipe acting as a manifold was attached vertically to the left side of the frame, through which air was blown by means of a motor driven fan (Model AK4L143A type 821, Franklin Electric Company, Bluffton, IN).

The wastewater application unit consisted of: (a) a wastewater storage tank, for storing the wastewater, (b) a pump, to transfer the wastewater from the storage tank to the growth troughs, (c) six valves, to control the amount of wastewater fed to each cell and (d) an irrigation system, for applying the wastewater onto the plant supporting trays in the growth troughs. The wastewater storage tank was constructed of plastic and had a capacity of approximately $100 \mathrm{~L}$. A mixing shaft, with a $40 \mathrm{~cm}$ diameter impeller, was installed through the center of the cover of the tank to agitate the wastewater in the tank. Four $2.5 \mathrm{~cm}$ baffles were installed vertically along the inside wall of the tank to promote complete mixing. A $1 \mathrm{hp}$ motor (Model NSI10RS3, Bodine Electric Company, Chicago, IL) with speed reducer was mounted on the tank cover to drive the mixing shaft and impeller. The wastewater storage tank was connected to the pump using TYGON tubing of $3.175 \mathrm{~cm}$ outside diameter. A variable speed pump (Model 110-23E, TAT Pumps Inc., Logan, OH) with a capacity of $138 \mathrm{~cm}^{3} \mathrm{rev}^{-1}$ was used to transfer the wastewater from the storage tank to the irrigation system. The pump was connected to the irrigation system using PVC tubing of $1.905 \mathrm{~cm}$ outside diameter. Six valves were used to control the amount of wastewater fed to each growth trough. The timing and duration of opening/closing of the valves were controlled by an electronic circuit. Each wastewater applicator was fabricated from stainless steel pipe with holes punched along the lower edge to allow the wastewater to flow out. The wastewater entered the applicator at the center of the top edge. To overcome the problem of clogging, a water line with six solenoid valves was attached to the applicator and was used to flush out the applicator after feeding periods. The wastewater application system was fully automated and consisted of a motor driven pulley arrangement on each shelf to which the applicator tubes were attached. The motors (Sigma Model 20-3424SG-24007, Faber Industrial Technologies, Clifton, NJ) ran at $6 \mathrm{rpm}$ and were controlled by an electronic circuit. The system was set up so that each applicator traveled $122 \mathrm{~cm}$ (3 tray lengths). When a guide on an applicator hit a microswitch located at each end of the shelf, the motor stopped. After a $3 \mathrm{sec}$ delay, the applicator traveled in the opposite direction. This process continued for the designated feeding time which was controlled by computer. Each compartment contained a sampling port located $2.0 \mathrm{~cm}$ from the bottom of the trough. Each sampling port was connected to a $2.7 \mathrm{~L}$ glass bottle using PVC tubing of $1.27 \mathrm{~cm}$ outside diameter and a valve.

A microcontroller (BASIC Stamp 2P24, Parallax, Inc., Rocklin, CA) was used to run the various components of the hydroponics system including the lighting, cooling, irrigation and supernatant collection units. Addressable latches were used to effectively increase the microcontroller's 24 input/output pins to the required number. The microcontroller was programmed using BASIC computer software (BASIC Stamp Windows Editor version 2.2.6, Parallax, Inc., Rocklin, CA). A real time clock (Dallas Semiconductor X1226, Maxim Integrated Products, Inc., Sunnyvale, CA) and a 1-Farad supercapacitor provided nonvolitile timing. A separate program (BASIC Stamp Windows Editor Version 2.2.6, Parallax, Inc., Rocklin, CA) was used to set the real time clock.

\section{MATERIALS AND METHODS}

Experimental materials: The barley seeds were purchased from Walker's Livestock, Dartmouth, Nova Scotia. The wastewater used in the study was obtained from an intensive, recirculating aquaculture facility stocked with Arctic charr (Salvelinus alpinus) located in Truro, Nova Scotia. The chemical analyses for the aquaculture wastewater are presented in Table 1.

Experimental procedure: The effects of wastewater application rate (at two levels) on the growth and yield of barley and the pollution reduction of the wastewater were investigated. The wastewater application rate was calculated based on the phosphorus requirement of barley and on the phosphorus concentration in the aquaculture wastewater. The calculated wastewater application rate $\left(690 \mathrm{~mL}\right.$ compartment $^{-1}$ day $\left.^{-1}\right)$ was doubled (1380 mL compartment ${ }^{-1}$ day $^{-1}$ ) to provide for the second application rate. The day length at a latitude of $45^{\circ} \mathrm{N}$ during the crop growing season (May 1st to Sept $31 \mathrm{st}$ ) is approximately $14 \mathrm{~h}$. Therefore, the lighting system was programmed to provide a daily photoperiod of $14 \mathrm{~h}$. The seed quantity was fixed at $300 \mathrm{~g} \mathrm{tray}^{-1}$.

On day 1 , the plant support trays were labeled and weighted using an analytical balance (Model PM30, Mettler Instrument Corporation, Hightstown, NJ). The required amounts of seed were also weighed using an 
Table 1: Chemical analysis of aquaculture wastewater

\begin{tabular}{lc}
\hline Parameter & Value $\left(\mathrm{mg} \mathrm{L}^{-1}\right)$ \\
\hline Total solids & $826.67 \pm 28.87$ \\
Suspended solids & $103.33 \pm 13.63$ \\
Total chemical oxygen demand & $157.97 \pm 9.320$ \\
Soluble chemical oxygen demand & $102.34 \pm 8.560$ \\
Ammonium-Nitrogen & $2.08 \pm 0.500$ \\
Nitrite-Nitrogen & $1.27 \pm 0.090$ \\
Nitrate-Nitrogen & $21.64 \pm 0.600$ \\
Total phosphorus & 6.30 \\
Orthophosphate & $4.49 \pm 0.180$ \\
Potassium & $74.67 \pm 0.320$ \\
Calcium & $59.90 \pm 0.950$ \\
Sodium & $114.67 \pm 0.580$ \\
Sulfur & $6.97 \pm 0.120$ \\
Chloride & $86.67 \pm 0.580$ \\
Magnesium & $5.06 \pm 0.070$ \\
Manganese & 0.20 \\
Iron & $0.03 \pm 0.010$ \\
Copper & 0.06 \\
Zinc & 0.20 \\
pH & $7.00 \pm 0.13$ \\
\hline
\end{tabular}

analytical balance (Model PM4600, Mettler Instrument Corporation, Hightstown, NJ). Each group of seeds was surface sterilized by soaking the seeds in $10 \%$ bleach for $20 \mathrm{~min}$ and then rinsing with distilled-deionized water. Surface sterilization of seeds was performed to limit problems associated with fungal infections observed in previous studies. The seeds were then placed on the trays in the growth troughs. With the valves controlling the sampling ports in the closed position, each growth trough was filled with tap water to a level such that the seeds were in contact with the water, but not submerged. The aeration system was turned on and pressure regulators were adjusted to $0.340 \mathrm{~atm}$. Two compartments were utilized as controls and contained wastewater only. The experiment was conducted in triplicate.

During the germination period (days 2-7), seed germination and seedling height were observed and recorded daily. Tap water was added to each compartment as required to compensate for losses due to evaporation. Effluent samples were collected from each compartment on day 8 before the addition of wastewater and refrigerated at $4{ }^{\circ} \mathrm{C}$ in labeled bottles until needed for chemical analyses.

During the growth period (days 8-21), the crop height in each tray was measured and recorded. The lighting, cooling and wastewater application systems were activated. Effluent samples were collected from each compartment on a daily basis before the addition of wastewater and refrigerated at $4{ }^{\circ} \mathrm{C}$ in labeled bottles until needed for chemical analyses. The lighting, cooling and wastewater application units were activated. The experiment was terminated on day 21 . Each tray was removed from its compartment and allowed to dry at room temperature $\left(22^{\circ} \mathrm{C}\right)$ for $24 \mathrm{~h}$. The biomass of each tray was measured and recorded. Crop samples were collected from each tray for nutritional analyses.

Chemical analyses: All effluent samples were analyzed for the following parameters: total solids (TS), total chemical oxygen demand (COD), ammonium-nitrogen $\left(\mathrm{NH}_{4}{ }^{+}-\mathrm{N}\right)$, nitrite-nitrogen $\left(\mathrm{NO}_{2}{ }^{-} \mathrm{N}\right)$, nitrate-nitrogen $\left(\mathrm{NO}_{3}{ }^{-} \mathrm{N}\right)$, phosphate-phosphorus $\left(\mathrm{PO}_{4}^{-3}-\mathrm{P}\right)$ and $\mathrm{pH}$. The $\mathrm{TS}, \mathrm{COD}, \mathrm{NO}_{2}{ }^{-} \mathrm{N}$ and $\mathrm{PO}_{4}^{-3}-\mathrm{P}$ analyses were performed according to procedures described in Standard Methods for the Examination of Water and Wastewater ${ }^{[6]}$. The $\mathrm{NH}_{4}{ }^{+} \mathrm{N}$ measurements were performed using the Kjeltec Auto Analyzer (Model 1030, Tecator, Höganäs, Sweden) according to the Kjeldahl method. The $\mathrm{NO}_{3}{ }^{-} \mathrm{N}$ analysis was performed according to the phenoldisulfonic acid technique described in Methods of Soil Analysis ${ }^{[7]}$. The $\mathrm{pH}$ of the wastewater was measured using a pH meter (Model 805MP, Fisher Scientific, Montreal, QC). Plant tissue analyses (energy, carbohydrates, crude protein, crude fat and crude fiber) were performed at Maxxam Analytics Inc., Mississauga, Ontario according to procedures described in Official Methods of Analysis of AOAC International ${ }^{[8]}$. The elemental composition $(\mathrm{Ca}, \mathrm{Cl}, \mathrm{Mg}, \mathrm{P}, \mathrm{K}, \mathrm{Na}, \mathrm{S}, \mathrm{B}, \mathrm{Cu}$, $\mathrm{Fe}, \mathrm{Mn}, \mathrm{Mo}, \mathrm{Se}$ and $\mathrm{Zn}$ ) of the wastewater and plant tissue was determined in the Minerals Engineering Center, Dalhousie University using flame atomic adsorption spectroscopy.

Statistical analysis: The effects of wastewater application rate on crop height and crop yield at harvest (day 21) were tested using a one-way analysis of variance (ANOVA) with differences considered significant at the $\mathrm{p}=0.05$ level $(95 \%$ confidence interval). The statistical analysis was performed using SPSS (SPSS 14.0.1, SPSS Inc., Chicago, IL).

\section{RESULTS AND DISCUSSION}

Crop growth: Within $48 \mathrm{~h}$ of beginning the experiment, the seeds in all trays began to absorb water and swell. After 2 days, the radicles (part of the plant embryo that develops into a root) had broken through the seed coats and were visible on $50-60 \%$ of the seeds. By day 3, the plumules (primary bud of a germinating seed) and root mats had started to develop. During the germination period, the barley crops in all compartments grew rapidly and fairly uniformly and 
appeared healthy with green color. At the end of the germination period (day 8) the barley seedlings were approximately $14.0 \mathrm{~cm}$ in height. During the growth period (days 8-21), the plants continued to grow rapidly and fairly uniformly and showed no signs of mineral deficiency or disease. The crop heights measured during the experiment are shown in Table 2. At the end of the growth period, the average plant heights were 31.0 and $36.0 \mathrm{~cm}$ for the crops that received 690 and 1380 $\mathrm{mL}$ of wastewater compartment ${ }^{-1}$ day $^{-1}$, respectively (Fig. 3). The wastewater application rate had a significant impact $(\mathrm{p}=0.009)$ on the crop height (Table 3). The crop height increased as the wastewater application rate was increased because the plants were provided with more nutrients ${ }^{[9-11]}$.

Table 2: Crop heights and yields at harvest

\begin{tabular}{lcccc}
\hline Replicate & $\begin{array}{l}\text { Flow rate } \\
\left(\mathrm{mL} \mathrm{comp}^{-1} \mathrm{day}^{-1}\right)\end{array}$ & $\begin{array}{l}\text { Height } \\
(\mathrm{cm})\end{array}$ & $\begin{array}{l}\text { Biomass } \\
\left(\mathrm{kg} \mathrm{tray}^{-1} *\right)\end{array}$ & $\begin{array}{l}\text { Crop yield } \\
\left(\mathrm{t} \mathrm{ha}^{-1}\right)\end{array}$ \\
\hline 1 & 690 & 31.0 & 0.883 & 59 \\
2 & 690 & 29.5 & 0.913 & 61 \\
3 & 690 & 32.5 & 0.826 & 55 \\
1 & 1380 & 37.0 & 1.200 & 80 \\
2 & 1380 & 35.0 & 1.240 & 83 \\
3 & 1380 & 36.0 & 1.271 & 85 \\
*: Tray area $=1497.20 \mathrm{~cm}^{2}$ & & &
\end{tabular}

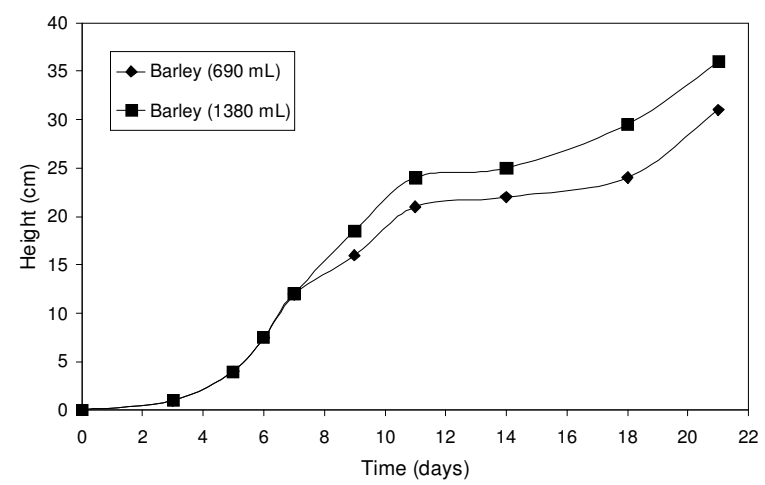

Fig. 3: Effect of wastewater application rate on the average crop height

Clarkson and Lane ${ }^{[12]}$ evaluated the feasibility of using hydroponically grown barley to reduce the mineral content of wastewater from an aquarium stocked with common carp (Cyprinus carpio) and rainbow trout (Oncorhynchus mykiss) and reported good plant growth of barley, which had reached a height of $20-22 \mathrm{~cm}$ in 6-10 days. Kamal and Ghaly ${ }^{[13]}$ investigated the use of hydroponically grown barley for reducing the nutrient content of wastewater from a recirculating aquaculture system stocked with tilapia and reported an average crop height of $25-26 \mathrm{~cm}$ after 21 days of growth.

Crop yield: The barley yields ranged from 55 to $61 \mathrm{t}$ $\mathrm{ha}^{-1}$ and from 80 to $85 \mathrm{t} \mathrm{ha}^{-1}$ for wastewater application rates of 690 and $1380 \mathrm{~mL}$ compartment $^{-1}$ day $^{-1}$, respectively. The wastewater application rate had a significant $\operatorname{impact}(\mathrm{p}=0.040)$ on the crop yield (Table 4). The crop yield increased as the wastewater application rate was increased due to the additional nutrients supplied to the plants ${ }^{[9-11]}$.

MacKenzie $^{[14]}$ evaluated the use of hydroponically grown wheat to reduce the nutrient content of an anaerobically digested dairy manure. The researcher reported crop yields of 22-140, 79-134 and 142-174 t $\mathrm{ha}^{-1}$ at wastewater application rates of 300, 600 and 900 $\mathrm{mL}$ compartment ${ }^{-1}$ day $^{-1}$, respectively. Pettersen ${ }^{[15]}$ examined the ability of hydroponically grown barley to reduce the nutrient salt content of aquaculture wastewater and reported barley yields ranging from 1 to $65 \mathrm{t} \mathrm{ha}^{-1}$ depending on light intensities and materials used for root support.

Effluent quality: During germination, seeds rapidly absorb water from the surrounding environment. The swelling that results from the rapid influx of water leads to rupture of the seed coat and leakage of internal substances from the seed. This rapid leakage of cellular and vacuolar constituents is referred to as seed exudation $^{[16]}$. Seed exudates generally consist of carbohydrates, amino acids, organic acids, inorganic ions and other miscellaneous compounds all of which alter the quality of the surrounding growth medium ${ }^{[17}$, 18]

Table 5 shows the influent and effluent TS, COD, $\mathrm{NH}_{4}{ }^{+}-\mathrm{N}, \mathrm{NO}_{2}^{-}-\mathrm{N}, \mathrm{NO}_{3}{ }^{-}-\mathrm{N}$ and $\mathrm{PO}_{4}{ }^{-3}-\mathrm{P}$ concentrations at days 8 and 21 of the experiment and the removal efficiencies for each water quality parameter. During the experiment, the average TS, $\mathrm{COD}, \mathrm{NH}_{4}{ }^{+}-\mathrm{N}, \mathrm{NO}_{2}{ }^{-}-\mathrm{N}$, $\mathrm{NO}_{3}{ }^{-} \mathrm{N}$ and $\mathrm{PO}_{4}{ }^{-3}-\mathrm{P}$ reductions ranged from 51.50 to $52.88 \%$, from 72.30 to $72.31 \%$, from 81.82 to $82.33 \%$, from 97.90 to $98.16 \%$, from 78.93 to $79.73 \%$ and from 84.70 to $86.30 \%$ at wastewater application rates of 690 and $1380 \mathrm{~mL}$ compartment ${ }^{-1}$ day $^{-1}$, respectively. The TS, COD, $\mathrm{NH}_{4}^{+}-\mathrm{N}, \mathrm{NO}_{2}^{-}-\mathrm{N}, \mathrm{NO}_{3}^{-}-\mathrm{N}$ and $\mathrm{PO}_{4}^{-3}-\mathrm{P}$ reductions were significantly influenced $(\mathrm{p}=0.000)$ by the presence of barley as compared to the controls, but were not significantly affected by wastewater application rate. 
Am. J. Agri. \& Biol. Sci., 2 (3): 168-183, 2007

Table 3: Results of a one-way ANOVA for crop heights as affected by wastewater application rate

\begin{tabular}{lccccc}
\hline Source & DF & SS & MS & F-value & p-value \\
\hline Total & 5 & 44.00 & & & \\
Wastewater application rate & 1 & 37.50 & 6.50 & 37.50 & 23.08 \\
Error & 4 & & 1.63 & 0.009 \\
\hline
\end{tabular}

Table 4: Results of a one-way ANOVA for crop yields as affected by wastewater application rate

\begin{tabular}{|c|c|c|c|c|c|}
\hline Source & DF & SS & MS & F-value & $\mathrm{p}$-value \\
\hline Total & 5 & 919.50 & & & \\
\hline Wastewater application rate & 1 & 888.17 & 888.17 & 113.38 & 0.000 \\
\hline Error & 4 & 31.33 & 7.83 & & \\
\hline
\end{tabular}

Table 5: Water quality parameters

\begin{tabular}{|c|c|c|c|c|c|c|c|c|}
\hline \multirow[b]{2}{*}{ Parameter } & \multirow{2}{*}{$\begin{array}{l}\text { Wastewater } \\
\text { Application } \\
\left(\mathrm{mLcomp}^{-}\right. \\
\left.{ }^{1} \text { day }^{-1}\right)\end{array}$} & \multirow[b]{2}{*}{ Treatment } & \multicolumn{3}{|c|}{ Input $^{\mathrm{a}}\left(\mathrm{mg} \mathrm{L}^{-1}\right)$} & \multirow[b]{2}{*}{$\begin{array}{l}\text { Effluent }^{\mathrm{b}} \\
\left(\mathrm{mg} \mathrm{L}^{-1}\right)\end{array}$} & \multicolumn{2}{|c|}{ Reduction } \\
\hline & & & Wastewater & $\begin{array}{c}\text { Released } \\
\text { substances }\end{array}$ & Total & & $\left(\mathrm{mg} \mathrm{L}^{-1}\right)$ & $(\%)$ \\
\hline \multirow[t]{4}{*}{ TS } & 690 & Control & $827 \pm 29$ & -- & $827 \pm 29$ & $600 \pm 14$ & 227 & 27.40 \\
\hline & & Barley & $827 \pm 29$ & $217 \pm 46$ & $1044 \pm 54$ & $491 \pm 21$ & 553 & 52.88 \\
\hline & 1380 & Control & $827 \pm 29$ & -- & $827 \pm 29$ & $625 \pm 20$ & 202 & 24.40 \\
\hline & & Barley & $827 \pm 29$ & $235 \pm 23$ & $1062 \pm 37$ & $515 \pm 8$ & 547 & 51.50 \\
\hline \multirow[t]{4}{*}{ COD } & 690 & Control & $158 \pm 9$ & -- & $158 \pm 9$ & $114 \pm 5$ & 44 & 27.62 \\
\hline & & Barley & $158 \pm 9$ & $148 \pm 15$ & $306 \pm 17$ & $72 \pm 7$ & 234 & 72.30 \\
\hline & 1380 & Control & $158 \pm 9$ & -- & $158 \pm 9$ & $129 \pm 6$ & 29 & 18.54 \\
\hline & & Barley & $158 \pm 9$ & $169 \pm 14$ & $327 \pm 16$ & $83 \pm 3$ & 243 & 72.31 \\
\hline \multirow[t]{4}{*}{$\mathrm{NH}_{4}{ }^{+}-\mathrm{N}$} & 690 & Control & $2.08 \pm 0.50$ & -- & $2.08 \pm 0.50$ & $0.50 \pm 0.71$ & 1.58 & 75.96 \\
\hline & & Barley & $2.08 \pm 0.50$ & $0.67 \pm .94$ & $2.75 \pm 1.06$ & $<0.5$ & 2.25 & 81.82 \\
\hline & 1380 & Control & $2.08 \pm 0.50$ & -- & $2.08 \pm 0.50$ & $1.25 \pm 1.00$ & 0.83 & 39.90 \\
\hline & & Barley & $2.08 \pm 0.50$ & $0.75 \pm 0.50$ & $2.83 \pm 0.71$ & $<0.5$ & 2.33 & 82.33 \\
\hline \multirow[t]{4}{*}{$\mathrm{NO}_{2}^{-}-\mathrm{N}$} & 690 & Control & $1.27 \pm 0.09$ & 0.00 & $1.27 \pm 0.09$ & $1.16 \pm 0.05$ & 0.11 & 8.66 \\
\hline & & Barley & $1.27 \pm 0.09$ & -- & $1.27 \pm 0.09$ & $0.02 \pm 0.01$ & 1.25 & 98.16 \\
\hline & 1380 & Control & $1.27 \pm 0.09$ & 0.00 & $1.27 \pm 0.09$ & $1.62 \pm 0.07$ & -0.35 & -27.56 \\
\hline & & Barley & $1.27 \pm 0.09$ & -- & $1.27 \pm 0.09$ & $0.03 \pm 0.01$ & 1.24 & 97.90 \\
\hline \multirow[t]{4}{*}{$\mathrm{NO}_{3}{ }^{-}-\mathrm{N}$} & 690 & Control & $21.64 \pm 0.60$ & -- & $21.64 \pm 0.60$ & $7.92 \pm 0.44$ & 13.72 & 63.54 \\
\hline & & Barley & $21.64 \pm 0.60$ & $7.51 \pm 0.10$ & $29.15 \pm 0.61$ & $6.14 \pm 0.27$ & 23.01 & 78.93 \\
\hline & 1380 & Control & $21.64 \pm 0.60$ & -- & $21.64 \pm 0.60$ & $9.01 \pm 0.51$ & 12.63 & 58.24 \\
\hline & & Barley & $21.64 \pm 0.60$ & $7.45 \pm 0.22$ & $29.09 \pm 0.64$ & $5.93 \pm 0.06$ & 23.16 & 79.73 \\
\hline \multirow[t]{4}{*}{$\mathrm{PO}_{4}-\mathrm{P}$} & 690 & Control & $4.49 \pm 0.18$ & -- & $4.49 \pm 0.18$ & $2.95 \pm 0.25$ & 1.54 & 34.30 \\
\hline & & Barley & $4.49 \pm 0.18$ & $2.29 \pm 0.56$ & $6.78 \pm 0.59$ & $0.92 \pm 0.17$ & 5.86 & 86.30 \\
\hline & 1380 & Control & $4.49 \pm 0.18$ & -- & $4.49 \pm 0.18$ & $3.54 \pm 0.36$ & 0.95 & 21.16 \\
\hline & & Barley & $4.49 \pm 0.18$ & $3.79 \pm 0.31$ & $8.28 \pm 0.36$ & $1.27 \pm 0.07$ & 7.01 & 84.70 \\
\hline
\end{tabular}

Ghaly et $a l^{[19]}$ evaluated the use of hydroponically grown barley to reduce the TS, $\mathrm{COD}, \mathrm{NO}_{2}^{-}-\mathrm{N}, \mathrm{NO}_{3}{ }^{-} \mathrm{N}$ and $\mathrm{PO}_{4}^{-3}-\mathrm{P}$ concentrations in wastewater from a recirculating aquaculture system stocked with tilapia. After 21 days of growth, the researchers reported average TS, COD, $\mathrm{NO}_{2}^{-}-\mathrm{N}, \mathrm{NO}_{3}^{-}-\mathrm{N}$ and $\mathrm{PO}_{4}^{-3}-\mathrm{P}$ reductions of $91.0,85.9,98.1,76.7$ and $93.6 \%$ at a wastewater application rate of $525 \mathrm{~mL}^{\text {compartment }}{ }^{-1}$ $\mathrm{day}^{-1}$, respectively. MacKenzie ${ }^{[14]}$ examined the ability of hydroponically grown wheat to reduce the TS, COD and $\mathrm{NH}_{4}{ }^{+}-\mathrm{N}$ concentrations in an anaerobically digested dairy manure. After 21 days of growth, the researcher reported TS, COD and $\mathrm{NH}_{4}{ }^{+}-\mathrm{N}$ reductions ranging from 64.6 to $87.2 \%$, from 81.9 to $92.3 \%$ and from 64.5 to $85.8 \%$ at wastewater applications rates of 300,600 and $900 \mathrm{~mL}$ compartment ${ }^{-1}$ day $^{-1}$. Clarkson and Lane ${ }^{[12]}$ evaluated the feasibility of utilizing a nutrient-film technique to reduce the mineral content of wastewater from an aquarium stocked with common carp $(C$. carpio) and rainbow trout (O. mykiss). During a four- 
week period, $\mathrm{NO}_{3}^{-}-\mathrm{N}$ and $\mathrm{PO}_{4}^{-3}-\mathrm{P}$ concentrations in the effluent were reduced from 33.03 to $3.03 \mathrm{mg} \mathrm{L}^{-1}$ and from 4.4 to $0.3 \mathrm{mg} \mathrm{L}^{-1}$, respectively.

Nutrition: Barley samples were collected from compartments that received wastewater at an application rate of $1380 \mathrm{~mL}$ compartment ${ }^{-1}$ day $^{-1}$ for nutritional analyses because the crop height and yield increased as the wastewater application rate was increased and the wastewater application rate did not have a significant affect on pollution reduction. Six major components were considered when analyzing the wastewater grown barley as potential fish feed: energy, carbohydrates, crude protein, crude fat, macroelements and microelements. Table 6 displays a comparison between the nutritional composition of the wastewater grown barley and the nutritional requirements of aquatic animals.

Energy: Energy is defined as the ability or capacity to do work. Aquatic animals derive energy through the catabolism of dietary carbohydrates, lipids and proteins within the body. Energy is essential for the maintenance of life processes including: cellular metabolism, growth, reproduction and physical activity. The ability of a food to supply energy is therefore of great importance in determining its nutritional value to animals. The mean gross energy value for carbohydrates, lipids and proteins has been estimated to be $17.2 \mathrm{~kJ} \mathrm{~g}^{-1}$ (4.1 $\left.\mathrm{kcal} \mathrm{g}^{-1}\right), 39.8 \mathrm{~kJ} \mathrm{~g}^{-1}\left(9.5 \mathrm{kcal} \mathrm{g}^{-1}\right)$ and $23.4 \mathrm{~kJ} \mathrm{~g}^{-1}(5.6$ $\mathrm{kcal} \mathrm{g}^{-1}$ ), respectively ${ }^{[20]}$.

Table 6: A comparison between the nutritional composition of the wastewater grown barley and the nutrient requirements of aquatic animals ${ }^{[22-30]}$

\begin{tabular}{|c|c|c|}
\hline Parameter & Barley & Fish Feed \\
\hline Energy $\left(\mathrm{MJ} \mathrm{kg}^{-1}\right)$ & 16.0 & $12-23$ \\
\hline Carbohydrates (\% dm) & 59.8 & $10-30$ \\
\hline Fiber (\% dm) & 27.17 & $1-12$ \\
\hline Proteins (\% dm) & 16.13 & $32-52$ \\
\hline Fats $(\% \mathrm{dm})$ & 4.4 & $4-28$ \\
\hline Calcium (\%) & $0.60 \pm 0.01$ & $0.03-2.90$ \\
\hline Chlorine (\%) & 1.96 & $0.10-0.50$ \\
\hline Magnesium (\%) & $0.29 \pm 0.00$ & $0.04-0.30$ \\
\hline Phosphorus (\%) & $0.84 \pm 0.02$ & $0.45-2.20$ \\
\hline Potassium (\%) & $3.80 \pm 0.01$ & $0.50-1.50$ \\
\hline Sodium (\%) & $1.34 \pm 0.01$ & $0.10-2.30$ \\
\hline Sulfur (\%) & $0.32 \pm 0.02$ & $0.30-1.70$ \\
\hline Boron $\left(\mathrm{mg} \mathrm{kg}^{-1}\right)$ & $13 \pm 2$ & -- \\
\hline Copper $\left(\mathrm{mg} \mathrm{kg}^{-1}\right)$ & $117 \pm 62$ & $3-10$ \\
\hline Iron $\left(\mathrm{mg} \mathrm{kg}^{-1}\right)$ & $1679 \pm 1255$ & $30-170$ \\
\hline Manganese $\left(\mathrm{mg} \mathrm{kg}^{-1}\right)$ & $121 \pm 7$ & $2.4-120$ \\
\hline Molybdenum $\left(\mathrm{mg} \mathrm{kg}^{-1}\right)$ & $1 \pm 0.74$ & -- \\
\hline Selenium $\left(\mathrm{mg} \mathrm{kg}^{-1}\right)$ & 1.2 & $0.15-0.40$ \\
\hline $\operatorname{Zinc}\left(\mathrm{mg} \mathrm{kg}^{-1}\right)$ & $3557 \pm 765$ & $15-240$ \\
\hline
\end{tabular}

Two important differences exist in the energy metabolism in fish and shellfish compared to terrestrial farm animals. First, unlike warm-blooded animals, fish and shellfish are aquatic ectotherms, which means that they have no internal metabolic mechanism for regulating their body temperature and therefore, do not have to expend energy to maintain a body temperature well above ambient conditions ${ }^{[21]}$. Second, the excretion of waste nitrogen requires less energy in fish and shellfish compared to terrestrial farm animals. Fish and shellfish do not have to convert ammonia, the end product of protein catabolism into less toxic substances (urea or uric acid) prior to excretion. Therefore, fish and shellfish can obtain 10-20\% more energy from the catabolism of proteins compared to terrestrial farm animals $^{[2]}$.

Providing the optimum energy level in the diets of fish and shellfish is important for the development of a healthy product. Because fish feed to meet their energy requirements, excess dietary energy may result in high fat deposition in the fish, decreased feed intake and reduced weight gain. Similarly, a diet with low energy content may result in reduced weight gain because the animal will utilize nutrients for energy provision rather than for tissue synthesis and growth. A number of factors are known to influence the energy requirements of fish and shellfish including: water temperature, animal size, physiological status and water quality and stress $^{[20]}$.

The wastewater grown barley had an energy content of $16.0 \mathrm{MJ} \mathrm{kg}^{-1}$, which meets the energy requirements of aquatic animals. These findings are slightly higher than those reported by other investigators. Sneath and McIntosh ${ }^{[31]}$ reported that the energy content of hydroponically grown barley ranged from 8.7 to $12 \mathrm{MJ} \mathrm{kg}^{-1}$. Mackowiak et al. ${ }^{[32]}$ reported an energy content of 9.54-10.84 $\mathrm{MJ} \mathrm{kg}^{-1}$ in hydroponically grown wheat.

Carbohydrates: Carbohydrates constitute the third most abundant group of organic molecules in the animal body ${ }^{[20]}$. They are produced by photosynthetic plants and contain carbon, hydrogen and oxygen in the ratio 1: 2: 1. Carbohydrates include sugars, starches, cellulose and other related compounds and serve as the principle source of metabolic energy in terrestrial farm animals. In fish and shellfish, no essential dietary requirement for carbohydrates has been established. Carbohydrates are included in fish and shellfish diets because they are an inexpensive source of dietary energy, they serve as a binding agent during feed manufacturing and they can increase feed palatability ${ }^{[2,33]}$. 
Carnivorous fish species (salmonids) have a limited ability to digest complex carbohydrates due to the weak amylotic activity in their digestive tract. By contrast, warm water omnivorous and herbivorous fish species such as carp, channel catfish, tilapia and eel have been found to be more tolerant of high dietary carbohydrate levels. Unlike terrestrial farm animals, most fish species have a relatively short gastro-intestinal tract with little microbial colonization. As a result, the intestinal cellulase activity of fish is weak or absent. Consequently, dietary cellulose or crude fiber has no utilizable energy value and in dietary excess has a negative impact on growth and feed efficiency ${ }^{[20]}$.

The wastewater grown barley had carbohydrate and crude fiber contents of 59.8 and $27.17 \%$, which exceeds the recommended dietary intake of aquatic animals. Sneath and McIntosh ${ }^{[31]}$ reported that the carbohydrate and crude fiber contents of hydroponically grown barley ranged from 61.3 to $68.85 \%$ and 7.35 to $15.2 \%$, respectively. Mackowiak et al. ${ }^{[32]}$ reported a crude fiber content of $17.5-24.8 \%$ for hydroponically grown wheat. McKeehen et $a l .{ }^{[34]}$ reported that the carbohydrate content in hydroponically grown wheat ranged from 58.9 to $73.9 \%$. Carbohydrates are not normally included as a large part of the diet due to their low nutritional content and poor digestibility. Cooking, extrusion and expansion are methods used to improve digestibility of carbohydrates $^{[25]}$.

Crude protein: Proteins are high molecular weight organic compounds essential to the structure and function of all living cells. They consist of amino acids joined by peptide bonds and are composed of 50-55\% carbon, $15-18 \%$ nitrogen, $20-23 \%$ oxygen, 6-8\% hydrogen and $0-4 \%$ sulfur ${ }^{[2,35]}$. Protein is required in the diet to provide essential amino acids and nitrogen for the synthesis of non-essential amino acids and other nitrogen containing compounds ${ }^{[20,33]}$.

Fish and shellfish have a high dietary protein requirement which is generally attributed to their carnivorous/omnivorous feeding habit and their preferential use of protein over carbohydrates as a dietary energy source ${ }^{[20]}$. Protein requirements vary depending on species cultured, rearing environment and size and age of the cultured organisms. Generally, herbivorous fish have lower protein requirements than omnivorous and carnivorous species, fish reared in low density systems (pond aquaculture) have lower protein requirements than fish reared in high density systems (recirculating aquaculture) and larger, older fish have lower protein requirements than younger, smaller fish[36]. Protein is typically the largest and most expensive component of an aquaculture $\operatorname{diet}^{[3]}$.
The wastewater grown barley had a crude protein content of $16.13 \%$, which does not meet the dietary requirements of fish and shellfish. These findings were quite comparable with those reported by other investigators. Ayuso et al. ${ }^{[37]}$ evaluated the effects of humic substances extracted from municipal wastes on barley growth and nutrient adsorption during hydroponic cultivation. The researchers reported that the crude protein content in the hydroponically grown barley ranged from 12.4 to $18.1 \%$. Mackowiak et al. ${ }^{[32]}$ reported that the crude protein content of hydroponically grown wheat ranged from 20.5 to 26.5\%. Sneath and McIntosh ${ }^{[31]}$ reported crude protein contents of $11.38-24.9 \%$ in hydroponically grown barley. Fishmeal is one of the major ingredients in fish feed and is the most common protein source. Other common protein sources include meat and bone meal ${ }^{[25]}$. Either of these could be used to supplement the crop with protein at the required amount.

Crude fat: Lipids (fats) are a heterogeneous group of organic compounds found in plant and animal tissues that are readily soluble in organic solvents such as benzene, chloroform and ether, but are only sparingly soluble in water. Lipids are required for the long-term storage of metabolic energy, to supply essential fatty acids, as carriers of fat soluble vitamins and for structure and control ${ }^{[20,38]}$. Major classes of lipids include fatty acids, glycerol-derived lipids (including fats, oils and phospholipids), sphingosine-derived lipids (including ceramides, cerebrosides, gangliosides and sphingomyelins), sterols and their derivatives, terpenes and their derivatives, certain aromatic compounds, long-chain alcohols and waxes.

Fatty acids are long chain organic acids having the general formula $\mathrm{CH}_{3}\left(\mathrm{C}_{\mathrm{X}} \mathrm{H}_{\mathrm{Y}}\right) \mathrm{COOH}$. The hydrocarbon chain is either saturated (only single bonds between adjacent carbon atoms) or unsaturated (double bonds between some of the adjacent carbon atoms) and usually contains an even number of carbon atoms $\left(\mathrm{C}_{14}\right.$ to $\left.\mathrm{C}_{24}\right)$ in straight chains ${ }^{[35]}$. In nature, fatty acids usually occur as triesters of glycerol and are called triacylglycerols or triglycerides ${ }^{[5]}$. Fatty acids are a major source of metabolic energy in fish for growth, reproduction and egg production ${ }^{[38]}$.

The crude fat content of the wastewater grown barley was $4.40 \%$, which just meets the dietary requirements of fish and shellfish. These findings were comparable to those reported by other investigators. Sneath and McIntosh ${ }^{[31]}$ reported crude fat contents of $3.18-9.27 \%$ in hydroponically grown barley. Mackowiak et al. ${ }^{[32]}$ reported that the crude fat content of hydroponically grown wheat ranged from 3.4 to 
6.9\%. McKeehan et al. ${ }^{[34]}$ reported a crude fat content of $1.0-1.7 \%$ in hydroponically grown wheat. Fish or vegetable oils can be added to the feed during manufacturing to increase the fat content in the diet.

Macroelements: Macroelements are required by the body in relatively large amounts $\left(>100 \mathrm{mg} \mathrm{kg}^{-1}\right.$ dry diet) and include calcium, chlorine, magnesium, phosphorus, potassium, sodium and sulphur. These elements function in cellular metabolism, have important roles in osmoregulation and acid-base balance and serve as structural components of tissues $^{[35]}$. The dietary macroelement requirements of fish and shellfish depends to a large extent upon the concentration of the element in the water body. This is because aquatic animals are able to directly absorb minerals through their gills, fins and skin from the surrounding water ${ }^{[39]}$.

Calcium: Calcium is an essential component of bone, cartilage and the crustacean exoskeleton and is necessary for the normal clotting of blood. Calcium is an activator for several enzymes including: pancreatic lipase, acid phosphatase, cholinesterase and succinic dehydrogenase. Calcium stimulates muscle contraction and regulates the transmission of nerve impulses. It also plays a key role in the regulation of cell membrane permeability and is essential for the adsorption of vitamin $B_{12}$ from the gastro-intestinal tract ${ }^{[20,23]}$.

The wastewater grown barley had an average calcium concentration of $0.60 \%$, which meets the dietary requirements of fish and shellfish. Kamal and Ghaly ${ }^{[13]}$ evaluated the nutritional content of barley cultured on an effluent from a recirculating aquaculture facility stocked with tilapia and reported a calcium concentration of $0.25 \%$ in the hydroponically grown barley. McKeehen et al. ${ }^{[34]}$ reported a calcium concentration of $0.44-0.53 \%$ in hydroponically grown wheat. Sneath and McIntosh ${ }^{[31]}$ reported a calcium concentration in hydroponically grown barley of 0.07 $0.13 \%$.

Chlorine: Chlorine is the main monovalent anion of extracellular fluids in the animal body. It is essential for the regulation of osmotic pressure and acid-base equilibrium. Chlorine also plays a role in the transport of oxygen and carbon dioxide in the blood and in the maintenance of digestive juice $\mathrm{pH}^{[20]}$.

The wastewater grown barley had an average chlorine concentrations of $1.96 \%$, which exceeds the dietary chlorine requirements of aquatic animals. However, there was no evidence in the literature to suggest that the chlorine concentrations observed in the wastewater grown plants would be detrimental to the healthy development of fish and shellfish. Pelletier and Besner ${ }^{[40]}$ reported that feeding a diet supplemented with $8-12 \%$ salt $(\mathrm{NaCl})$ did not significantly affect the plasma osmotic pressure, electrolyte concentrations and gill ATPase activity of brood charr (Salvelinus fontinalis) raised in freshwater. Salman and Eddy ${ }^{[41]}$ investigated the effect of increased dietary salt on growth and nutrition of rainbow trout using a commercial trout food reconstituted to contain 4.5, 9.2 and $11.6 \% \mathrm{NaCl}$. The researchers reported that during a 14 week period food intake, appetite and growth rate were not affected by dietary salt concentrations. Staurnes and Finstad ${ }^{[42]}$ conducted an experiment in which Arctic charr (Salvelinus alpinus) smolts were fed pelleted feed with a $\mathrm{NaCl}$ content of either 1.5 and $9.5 \%$ for 6 weeks before release to the ocean. The researchers reported no differences in growth before release between fish fed the two diets. However, smolts fed the $9.5 \% \mathrm{NaCl}$ diet had a higher level of gill $\mathrm{Na}^{+} / \mathrm{K}^{+}-$ ATPase activity, better osmoregulatory ability and higher recapture and growth rates than those fed the $1.5 \% \mathrm{NaCl}$ diet.

Magnesium: Magnesium has a number of biological functions. Like calcium, it is an essential component of bone, cartilage and the crustacean exoskeleton. Magnesium is an activator of several key enzyme systems including kinases and mutases. It stimulates muscle and nerve contractions, is involved in the regulation of intracellular acid-base balance and plays an important role in carbohydrate, protein and lipid metabolism $^{[20,23]}$.

The wastewater grown barley had an average magnesium concentration of $0.29 \%$, which meets the dietary magnesium requirements of fish and shellfish. Sneath and McIntosh ${ }^{[31]}$ reported that the magnesium concentration in hydroponically grown barley ranged from 0.03 to $0.21 \%$. Steinberg et al. ${ }^{[43]}$ reported a magnesium concentration of $0.45 \%$ in hydroponically grown wheat. Kaushik et al..$^{[44]}$ reported that the magnesium concentration in 12 day old wheat seedlings cultured on sugarmill effluent was $1.41 \%$.

Phosphorus: The biological functions of phosphorus are numerous. Like calcium and magnesium, phosphorus is an essential component of bone, cartilage and the crustacean exoskeleton. It is an essential component of phospholipids, nucleic acids and high energy phosphate esters (ATP, ADP and AMP). Inorganic phosphates also help to regulate the acid-base balance of animal body fluids ${ }^{[20,23]}$.

The average phosphorus concentration in the wastewater grown barley was $0.84 \%$, which meets the dietary phosphorus requirements of fish and shellfish. 
Ghaly et al. ${ }^{[19]}$ evaluated the nutrient composition of barley cultured on an effluent from a recirculating aquaculture system stocked with tilapia and reported a phosphorus concentration of $0.79 \%$ in the hydroponically grown barley. Mackowiak et al. . $^{[32]}$ reported that the phosphorus content in hydroponically grown wheat ranged from 0.74 to $1.14 \%$. Ayuso et $a l .{ }^{[37]}$ reported a phosphorus concentration of 0.95 $1.61 \%$ in barley during hydroponic cultivation on humic substances.

Potassium: Potassium is the major cation of intracellular fluid in the animal body. It is responsible for the regulation of intracellular osmotic pressure and acid-base equilibrium. It stimulates muscle contraction and is required for glycogen and protein synthesis and the metabolic breakdown of glucose ${ }^{[20]}$.

The wastewater grown barley had an average potassium concentration of $3.80 \%$, which exceeds the potassium requirements of aquatic animals. Kamal and Ghaly ${ }^{[13]}$ reported a potassium concentration of $3.54 \%$ in barley cultured on effluent from a recirculating aquaculture facility. Steinberg et al. ${ }^{[43]}$ reported that after 22 days the potassium concentration in hydroponically grown wheat was $2.78 \%$. McKeehen $e t$ $a l^{[34]}$ reported that the potassium concentration in hydroponically grown wheat ranged from 4.11 to $6.69 \%$. The effects of excess dietary potassium differ between finfish and shellfish. Yueming et al. ${ }^{[45]}$ reported that excess potassium in the diet of African catfish depressed growth and nutrient utilization efficiency and reduced body fat and protein deposition. Shiau and $\mathrm{Hsieh}^{[46]}$ conducted an experiment to determine the dietary potassium requirement for juvenile hybrid tilapia (Oreochromis niloticus $\times O$. aureus). The researchers reported that weight gain was significantly higher in fish receiving diets supplemented with $0.2,0.3$ and $0.4 \%$ potassium than in fish fed a diet supplemented with $1.0 \%$ potassium. Zhu et al. ${ }^{[47]}$ examined the effects of dietary potassium concentrations $(1.09,1.53,2.49$ and $3.46 \%)$ on juvenile shrimp (Litopenaeus vannamei). After an 8 week period, the researchers reported that the dietary potassium concentrations had no significant effects on survival, molting, shrimp body potassium content, final body weights and feed consumption.

Sodium: Sodium is the main monovalent cation of extracellular fluids in the animal body. Its principal function is the regulation of osmotic pressure and the maintenance of acid-base equilibrium. Sodium also has an effect on muscle contraction and plays a role in the absorption of carbohydrates ${ }^{[20]}$.
The wastewater grown barley had an average sodium concentration of $1.34 \%$, which meets the dietary requirements of fish and shellfish. Ghaly et al. ${ }^{[19]}$ reported sodium concentrations of $2.85 \%$ in hydroponically grown barley. Sneath and McIntosh ${ }^{[31]}$ reported that the sodium concentration in hydroponically grown barely ranged from 0.03 to $0.21 \%$.

Sulphur: Sulphur is an essential component of the amino acids methionine and cystine, the vitamins thiamine and biotin, the hormone insulin and the crustacean exoskeleton. It also plays a role in several key enzyme systems ${ }^{[20]}$.

The wastewater grown barley had an average sulphur content of $0.32 \%$, which meets the dietary requirements of fish and shellfish. Sneath and McIntosh $^{[31]}$ reported a sulphur concentration of 0.16 $0.22 \%$ in hydroponically grown barley. Steinberg et $a l^{[43]}$ reported that the sulphur concentration in hydroponically grown wheat was $0.63 \%$. Mackowiak et $a l^{[32]}$ reported that the sulphur concentration in hydroponically grown wheat ranged from 0.27 to $0.36 \%$.

Microelements: Microelements are required by the body in trace amounts $\left(<100 \mathrm{mg} \mathrm{kg}^{-1}\right.$ dry diet $)$ and include boron, copper, iron, manganese, molybdenum, selenium and zinc ${ }^{[39]}$. The uptake and toxicity of dietborne metals in fish and shellfish are not well understood $^{[48]}$.

Boron: Although studies have shown that boron is essential for embryonic growth in some aquatic animals, the dietary boron requirement of fish and shellfish has not be established ${ }^{[49-50]}$. The boron concentration in the wastewater grown barley was $13 \mathrm{mg} \mathrm{kg}^{-1}$. Steinberg et al. ${ }^{[43]}$ reported that the boron concentration in hydroponically grown wheat was $80 \mathrm{mg} \mathrm{kg}$. McKeehen et al. ${ }^{[34]}$ reported a boron concentration of $23-93 \mathrm{mg} \mathrm{kg}^{-1}$ in hydroponically grown wheat.

Copper: Copper is an essential component of numerous oxidation-reduction systems. It is involved in iron metabolism, hemoglobin synthesis and red blood cell production and maintenance. Copper is also necessary for the formation of the pigment melanin, bone and connective tissue and for maintaining the integrity of the myelin sheath of nerve fibers ${ }^{[20,23,39]}$.

The copper concentration in the wastewater grown barley was $117 \mathrm{mg} \mathrm{kg}^{-1}$. Ayuso et al. ${ }^{[37]}$ evaluated the effects of humic substances extracted from municipal wastes on barley growth and nutrient adsorption during hydroponic cultivation and reported that the copper 
concentration in the hydroponically grown barley ranged from 12 to $76 \mathrm{mg} \mathrm{kg}^{-1}$. Sneath and McIntosh ${ }^{[31]}$ reported that the copper concentration in hydroponically grown barley ranged from 6 to $11 \mathrm{mg} \mathrm{kg}^{-1}$. Mackowiak et al. ${ }^{[32]}$ reported a copper concentration of $10-13 \mathrm{mg}$ $\mathrm{kg}^{-1}$ in hydroponically grown wheat. The dietary copper requirement of fish and shellfish differs depending on the species cultured and the age of the cultured organisms. Common carp and rainbow trout have a dietary copper requirement of $3 \mathrm{mg} \mathrm{kg}^{-1}$ dry diet; channel catfish require $5 \mathrm{mg} \mathrm{kg}^{-1}$ dry diet and Atlantic salmon parr require 5 to $10 \mathrm{mg} \mathrm{kg}^{-1} \mathrm{dry}_{\text {diet }}^{[48]}$. Copper is required in the diet of most fish species at concentrations of 3 to $10 \mathrm{mg} \mathrm{kg}^{-1}$ dry diet, but some species may require higher concentrations during rapid growth phases of their lifecycle. According to Berntssen et al. ${ }^{[51]}$ rapidly growing Atlantic salmon fry have a dietary copper requirement of $35 \mathrm{mg} \mathrm{kg}^{-1}$. Table 7 summarizes the effects of dietborne copper on different fish species.

Iron: Iron is an essential component of the respiratory pigments hemoglobin and myoglobin and is necessary for oxygen and electron transport within the body. It is also an essential component of several enzyme systems including cytochromes, catalases, peroxidases, oxidases and dehydrogenases ${ }^{[20,23,39]}$.

Lanno et al. ${ }^{[54]}$ the wastewater grown barley had an average iron concentration of $1679 \mathrm{mg} \mathrm{kg}^{-1}$, which exceeds the dietary requirements of fish and shellfish. Mackowiak et al.$^{[32]}$ reported an iron concentration of $147-1624 \mathrm{mg} \mathrm{kg}{ }^{-1}$ in hydroponically grown wheat. Ayuso et al. ${ }^{[37]}$ evaluated the effects of humic substances extracted from municipal wastes on barley growth and nutrient adsorption during hydroponic cultivation and reported an reported an iron concentration in the plant ranging from 96 to $672 \mathrm{mg}$ $\mathrm{kg}^{-1}$. Ghaly et al. ${ }^{[19]}$ reported an iron concentration of $225 \mathrm{mg} \mathrm{kg}^{-1}$ in barley cultured on an effluent from a recirculating aquaculture facility. Table 8 summarizes the effects of dietborne iron on different fish species.

Manganese: Manganese is an activator of enzymes responsible for phosphate group transfers including phosphate transferases and phosphate dehydrogenases. Manganese is a component of or a cofactor for several key enzyme systems and as such is essential for bone formation, the regeneration of red blood cells, carbohydrate and lipid metabolism and the reproductive cycle $^{[20,23,39]}$.

The average manganese concentration in the wastewater grown barley was $121 \mathrm{mg} \mathrm{kg}^{-1}$, which meets the dietary manganese requirement of fish and shellfish. Kamal and Ghaly ${ }^{[13]}$ reported that the manganese concentrations in hydroponically grown barley was $40 \mathrm{mg} \mathrm{kg}^{-1}$. Steinberg et al. $^{[43]}$ reported a manganese concentration of $123 \mathrm{mg} \mathrm{kg}^{-1}$ in hydroponically grown wheat. Sneath and McIntosh ${ }^{[31]}$ reported that the manganese concentration in hydroponically grown barley ranged from 21 to $27 \mathrm{mg} \mathrm{kg}^{-1}$.

Molybdenum: Although molybdenum is involved in enzymes systems responsible for purine metabolism and sulfite oxidation, the dietary molybdenum requirement of fish and shellfish is not defined ${ }^{[20,23]}$.

The wastewater grown barley had an average molybdenum concentrations of $1 \mathrm{mg} \mathrm{kg}^{-1}$. Steinberg et al. ${ }^{[43]}$ reported a molybdenum concentration of $18 \mathrm{mg}$ $\mathrm{kg}^{-1}$ in hydroponically grown wheat. Mackowiak et $a l .^{[32]}$ reported that the molybdenum concentration in hydroponically grown wheat ranged from 0.77 to $0.89 \mathrm{mg} \mathrm{kg}^{-1}$. McKeehen et al. ${ }^{[34]}$ reported that the molybdenum concentration in hydroponically grown wheat was $3 \mathrm{mg} \mathrm{kg}^{-1}$.

Selenium: Selenium is an essential component of the enzyme glutathione peroxidase and as such serves to protect cellular tissues and membranes against oxidative damage. It is involved in the synthesis of ubiquinone and as such is involved in cellular electron transport. It also influences the absorption and retention of vitamin $\mathrm{E}^{[20,23]}$.

The average selenium concentration in the wastewater grown barley was $1.2 \mathrm{mg} \mathrm{kg}^{-1}$, which exceeds the dietary requirement of fish and shellfish. Sneath and McIntosh ${ }^{[31]}$ reported that the selenium concentration in hydroponically grown barley was 0.9 $\mathrm{mg} \mathrm{kg}{ }^{-1}$. Table 9 summarizes the effects of dietborne selenium on different fish species.

Zinc: Zinc serves as a component of or a cofactor for many important enzymes systems and thus plays an important role in carbohydrate, lipid and protein metabolism. It is also involved in the synthesis and metabolism of nucleic acids and plays a role in wound healing ${ }^{[20,23]}$.

The wastewater grown barley had an average zinc concentration $3557 \mathrm{mg} \mathrm{kg}^{-1}$, which exceeds the dietary zinc requirements of aquatic animals. Ghaly et al. ${ }^{[19]}$ reported an average zinc concentration of $1040 \mathrm{mg} \mathrm{kg}^{-1}$ in barley cultured on an effluent from a recirculating aquaculture facility. Ayuso et al. ${ }^{[37]}$ reported zinc concentrations of $26-246 \mathrm{mg} \mathrm{kg}^{-1}$ in barley hydroponically cultured on humic substances extracted from municipal wastes. Steinberg et al. ${ }^{[43]}$ reported a zinc concentration of $37 \mathrm{mg} \mathrm{kg}^{-1}$ in hydroponically grown wheat. Table 10 summarizes the effects of dietborne zinc on different fish species. 
Am. J. Agri. \& Biol. Sci., 2 (3): 168-183, 2007

Table 7: The effects of dietborne copper on different fish species

\begin{tabular}{|c|c|c|c|c|c|c|}
\hline Species & $\begin{array}{l}\text { Lifecycle } \\
\text { stage }\end{array}$ & $\begin{array}{l}\text { Form } \\
\text { of metal }\end{array}$ & $\begin{array}{c}\text { Dietborne } \\
\text { concentration } \\
\left(\mathrm{mg} \mathrm{kg} \mathrm{k}^{-1}\right)\end{array}$ & $\begin{array}{l}\text { Duration } \\
\text { (days) }\end{array}$ & Comments & Reference \\
\hline $\begin{array}{l}\text { Atlantic } \\
\text { salmon }\end{array}$ & parr & $\mathrm{CuSO}_{4} \cdot 5 \mathrm{H}_{2} \mathrm{O}$ & 5,34 and 691 & 28 & $\begin{array}{l}\text { Changes in intestinal pathology and } \\
\text { reduction in growth rates at } \\
\text { concentrations } \geq 34 \mathrm{mg} \mathrm{Cu} \mathrm{kg}^{-1} \text {. No } \\
\text { effect on survival rates. }\end{array}$ & Berntssen et al. ${ }^{[52]}$ \\
\hline $\begin{array}{l}\text { Atlantic } \\
\text { salmon }\end{array}$ & parr & $\mathrm{CuSO}_{4} \cdot 5 \mathrm{H}_{2} \mathrm{O}$ & $\begin{array}{c}5,10,50 \text { and } \\
100\end{array}$ & 84 & $\begin{array}{l}\text { No growth retardation among different } \\
\text { dietary treatments. }\end{array}$ & Lorentzen et al. ${ }^{[53]}$ \\
\hline $\begin{array}{l}\text { Atlantic } \\
\text { salmon }\end{array}$ & fry & $\mathrm{CuSO}_{4} \cdot 5 \mathrm{H}_{2} \mathrm{O}$ & $\begin{array}{l}5,35,500 \\
700,900 \text { and } \\
1750\end{array}$ & 84 & $\begin{array}{l}\text { Growth was significantly reduced at } \\
\text { dietary copper concentrations } \geq 500 \mathrm{mg} \\
\mathrm{kg}-1 \text { and whole body contents of } \\
\text { protein, glycogen and Se were } \\
\text { significantly reduced compared to } \\
\text { controls. }\end{array}$ & Berntssen et al..$^{[51]}$ \\
\hline Rainbow trout & fry & $\mathrm{CuSO}_{4} \cdot 5 \mathrm{H}_{2} \mathrm{O}$ & $\begin{array}{l}9.0,37,83 \\
171,287,730 \\
1585 \text { and } \\
3088\end{array}$ & 56 & $\begin{array}{l}\text { Reduced feed intakes and weight gains } \\
\text { and increased mortalities in trout reared } \\
\text { on test diets containing } \geq 730 \mathrm{mg} \mathrm{Cu} \\
\mathrm{kg}^{-1} \text { diet. }\end{array}$ & Lanno et al..$^{[54]}$ \\
\hline Rainbow trout & fry & $\mathrm{CuSO}_{4} \cdot 5 \mathrm{H}_{2} \mathrm{O}$ & $\begin{array}{l}8.5,132,258 \\
403,511 \text { and } \\
664\end{array}$ & $\begin{array}{l}112 \text { and } \\
168\end{array}$ & $\begin{array}{l}\text { At } 16 \text { weeks, reduced weight gain was } \\
\text { observed in trout reared on the test diet } \\
\text { containing } 664 \mathrm{mg} \mathrm{Cu} \mathrm{kg}^{-1} \text { diet. At } 24 \\
\text { weeks, the difference in body weight } \\
\text { had disappeared. Mortalities did not } \\
\text { differ between dietary treatments. }\end{array}$ & Lanno et al..$^{[54]}$ \\
\hline
\end{tabular}

Table 8: The effects of dietborne iron on different fish species

\begin{tabular}{|c|c|c|c|c|c|c|}
\hline Species & $\begin{array}{l}\text { Lifecycle } \\
\text { stage }\end{array}$ & $\begin{array}{c}\text { Form } \\
\text { of metal }\end{array}$ & $\begin{array}{c}\text { Dietborne } \\
\text { concentration } \\
\left(\mathrm{mg} \mathrm{kg}^{-1}\right)\end{array}$ & $\begin{array}{l}\text { Duration } \\
\text { (days) }\end{array}$ & Comments & Reference \\
\hline $\begin{array}{l}\text { African } \\
\text { catfish }\end{array}$ & juvenile & $\begin{array}{c}\mathrm{FeSO}_{4} \cdot 7 \mathrm{H} \\
{ }_{2} \mathrm{O}\end{array}$ & 663.5 and 6354.4 & 35 & $\begin{array}{l}\text { Reduced growth was observed in catfish } \\
\text { reared on the test diet containing } 6354.4 \mathrm{mg} \\
\mathrm{Fe} \mathrm{kg}^{-1} \text {. Tissue concentrations (muscle, liver } \\
\text { and plasma) were unaffected by dietary } \\
\text { regime. Evidence of heightened oxidative } \\
\text { stress in catfish consuming diets high in iron } \\
\text { and significant depletion of vitamin E from } \\
\text { livers. }\end{array}$ & $\begin{array}{l}\text { Baker and } \\
\text { Martin }^{[55]}\end{array}$ \\
\hline Hybrid tilapia & -- & $\begin{array}{c}\mathrm{FeC}_{6} \mathrm{H}_{5} \mathrm{O}_{7} \\
\cdot \mathrm{H}_{2} \mathrm{O}\end{array}$ & $\begin{array}{c}0,10,30,50 \\
100,150,200 \\
\quad \text { and } 400\end{array}$ & 56 & $\begin{array}{l}\text { Survival of fish was not affected by dietary } \\
\text { treatment. Weight gain was highest in tilapia } \\
\text { reared on the test diet containing } 150 \mathrm{mg} \mathrm{Fe} \\
\mathrm{kg}^{-1} \text {. }\end{array}$ & $\begin{array}{l}\text { Shiau and } \\
\mathrm{Su}^{[56]}\end{array}$ \\
\hline $\begin{array}{l}\text { Channel } \\
\text { catfish }\end{array}$ & juvenile & $\begin{array}{c}\mathrm{FeSO}_{4} \cdot 7 \mathrm{H} \\
{ }_{2} \mathrm{O}\end{array}$ & $\begin{array}{c}196,246,296 \\
396,596,996 \\
\text { and } 1796\end{array}$ & 84 & $\begin{array}{l}\text { Weight gain was not affected by dietary iron } \\
\text { up to } 996 \mathrm{mg} \mathrm{Fe} \mathrm{kg}{ }^{-1} \text {. Increasing dietary iron } \\
\text { level up to } 1796 \mathrm{mg} \mathrm{kg}^{-1} \text { significantly reduced } \\
\text { weight gain. Feed intake and survival were not } \\
\text { affected by dietary regime. WBC, hematocrit } \\
\text { and hemoglobin levels did not differ among } \\
\text { fish receiving various dietary treatments. }\end{array}$ & $\begin{array}{l}\text { Lim and } \\
\text { Klesius }^{[57]}\end{array}$ \\
\hline
\end{tabular}

\section{CONCLUSIONS}

The barley plants grew rapidly and fairly uniformly and showed no signs of mineral deficiency or disease in the hydroponics system. At the end of the experiment, the average crop heights and yields were 31.0 and 36.0 $\mathrm{cm}$ and 59 and $83 \mathrm{t} \mathrm{ha}^{-1}$ at wastewater application rates of 690 and $1380 \mathrm{~mL}$ compartment ${ }^{-1}$ day $^{-1}$, respectively. The hydroponics system reduced the TS, $\mathrm{COD}, \mathrm{NH}_{4}{ }^{+}-$ $\mathrm{N}, \mathrm{NO}_{2}^{-}-\mathrm{N}, \mathrm{NO}_{3}^{-}-\mathrm{N}$ and $\mathrm{PO}_{4}^{-3}-\mathrm{P}$ by $51.5-52.9,72.3-$ $72.3,81.8-82.3,97.9-98.2,78.9-79.7$ and $84.7-86.3 \%$, respectively. The barley plants that received wastewater at an application rate of $1380 \mathrm{~mL}$ compartment ${ }^{-1}$ day $^{-1}$ had higher heights and yields and were therefore collected for nutritional analyses. The wastewater grown barley met the energy, fat, $\mathrm{Ca}, \mathrm{Mg}, \mathrm{P}, \mathrm{Na}, \mathrm{S}$ and $\mathrm{Mn}$ dietary requirements of aquatic animals. It exceeded the carbohydrate, crude fiber, $\mathrm{Cl}, \mathrm{K}, \mathrm{Cu}, \mathrm{Fe}, \mathrm{Se}$ and $\mathrm{Zn}$ dietary requirements of fish and shellfish. Carbohydrates are not normally included as a large part of the diet due to their low nutritional content and poor digestibility. Crude fiber has no utilizable energy value for fish and shellfish and in dietary excess has a negative impact on growth and feed efficiency. Studies 
Am. J. Agri. \& Biol. Sci., 2 (3): 168-183, 2007

Table 9: The effects of dietborne selenium on different fish species

\begin{tabular}{|c|c|c|c|c|c|c|}
\hline Species & $\begin{array}{l}\text { Lifecycle } \\
\text { stage }\end{array}$ & $\begin{array}{c}\text { Form } \\
\text { of metal }\end{array}$ & $\begin{array}{c}\text { Dietborne } \\
\text { concentration } \\
\left(\mathrm{mg} \mathrm{kg}^{-1}\right)\end{array}$ & $\begin{array}{c}\text { Duration } \\
\text { (days) }\end{array}$ & Comments & Reference \\
\hline Grouper & juvenile & $\begin{array}{c}\text { Selenomet } \\
\text { hionine }\end{array}$ & $\begin{array}{l}0.21,0.77 \\
1.38,2.02,2.70 \\
\quad \text { and } 4.00\end{array}$ & 56 & $\begin{array}{l}\text { Weight gain and feed efficiency were highest in } \\
\text { fish fed a diet with } 0.77 \mathrm{mg} \mathrm{SE} \mathrm{kg}^{-1} \text { and lowest } \\
\text { in fish fed a diet with } 4.00 \mathrm{mg} \mathrm{kg}^{-1} \text {. Hepatic } \\
\text { glutathione peroxidase activity was highest in } \\
\text { fish fed diets with } \geq 2.02 \mathrm{mg} \mathrm{Se} \mathrm{kg}^{-1} \text {. }\end{array}$ & $\begin{array}{l}\text { Lin and } \\
\text { Shiau }^{[58]}\end{array}$ \\
\hline $\begin{array}{l}\text { Rainbow } \\
\text { trout }\end{array}$ & juvenile & $\mathrm{Na}_{2} \mathrm{SeO}_{3}$ & $\begin{array}{c}0.6,6.6 \text { and } \\
11.4\end{array}$ & 140 & $\begin{array}{l}\text { Fish reared on the highest level of dietary } \\
\text { selenium had a significant reduction in body } \\
\text { weight and increased mortality. Hematocrit, } \\
\text { plasma calcium, glucose and protein levels did } \\
\text { not vary significantly. }\end{array}$ & Hicks et al. ${ }^{[59]}$ \\
\hline $\begin{array}{l}\text { Atlantic } \\
\text { salmon }\end{array}$ & adult & -- & 0.66 and 2.66 & 270 & $\begin{array}{l}\text { Dietary treatment had no significant effects on } \\
\text { growth, serum protein content, serum } \\
\text { glutathione peroxidase activity, blood } \\
\text { hemoglobin and hematocrit. }\end{array}$ & $\begin{array}{l}\text { Julshamn et } \\
a l .{ }^{[60]}\end{array}$ \\
\hline
\end{tabular}

Table 10: The effects of dietborne zinc on different fish species

\begin{tabular}{|c|c|c|c|c|c|c|}
\hline Species & $\begin{array}{l}\text { Lifecycle } \\
\text { stage }\end{array}$ & $\begin{array}{l}\text { Form } \\
\text { of metal }\end{array}$ & $\begin{array}{l}\text { Dietborne } \\
\text { concentration } \\
\left(\mathrm{mg} \mathrm{kg}^{-1}\right)\end{array}$ & $\begin{array}{l}\text { Duration } \\
\text { (days) }\end{array}$ & Comments & Reference \\
\hline $\begin{array}{l}\text { Common } \\
\text { carp }\end{array}$ & juvenile & $\begin{array}{c}\mathrm{ZnSO}_{4} \cdot 7 \\
\mathrm{H}_{2} \mathrm{O}\end{array}$ & $\begin{array}{c}294,1007 \text { and } \\
1974\end{array}$ & 56 & Reduced growth rates compared to controls. & $\begin{array}{l}\text { Jeng and } \\
\text { Sun }^{[61]}\end{array}$ \\
\hline $\begin{array}{l}\text { Atlantic } \\
\text { salmon }\end{array}$ & juveniles & $\begin{array}{c}\mathrm{ZnSO}_{4} \cdot 7 \\
\mathrm{H}_{2} \mathrm{O}\end{array}$ & $\begin{array}{c}\text { 17.6, } 27.6 \\
36.3,67.2 \text { and } \\
101\end{array}$ & 56 & $\begin{array}{l}\text { Fish growth was not significantly influenced by } \\
\text { dietary zinc concentration. No significant } \\
\text { difference in hematological values. }\end{array}$ & $\begin{array}{l}\text { Maage and } \\
\text { Julshamn }{ }^{[29]}\end{array}$ \\
\hline Nile tilapia & fingerling & $\begin{array}{c}\mathrm{ZnSO}_{4} \cdot 7 \\
\mathrm{H}_{2} \mathrm{O}\end{array}$ & $\begin{array}{l}0,5,10,20,30 \\
40,50,60,70 \\
80,90 \text { and } 100\end{array}$ & 70 & $\begin{array}{l}\text { Reduced growth rates at concentrations } \geq 60 \\
\mathrm{mg} \mathrm{Zn} \mathrm{kg}^{-1} \text { diet. }\end{array}$ & $\begin{array}{l}\text { Eid and } \\
\text { Ghonim }^{[62]}\end{array}$ \\
\hline $\begin{array}{l}\text { Common } \\
\text { carp } \\
\text { Grass carp } \\
\text { Blue tilapia }\end{array}$ & fry & $\begin{array}{c}\mathrm{ZnSO}_{4} \cdot 7 \\
\mathrm{H}_{2} \mathrm{O}\end{array}$ & 4 and 2000 & 56 & $\begin{array}{l}\text { Significant accumulation of zinc in the } \\
\text { digestive tract tissue of common carp. }\end{array}$ & $\begin{array}{l}\text { Sun and } \\
\text { Jeng }\end{array}$ \\
\hline
\end{tabular}

have shown that excess dietary $\mathrm{Cu}, \mathrm{Fe}, \mathrm{Se}$ and $\mathrm{Zn}$ can cause reduced feed intake, weight gain and growth rates in fish and shellfish. Barley did not contain sufficient amounts of protein to meet the dietary requirements of fish and shellfish. Common protein sources that could be used for supplementation included fishmeal, bone meal and blood meal.

\section{ACKNOWLEDGMENTS}

The research was funded by Agriculture and AgriFood Canada.

\section{REFERENCES}

1. FAO., 2004. The State of World Fisheries and Aquaculture 2004. [online] Available: ftp:// ftp.fao.org/docrep/fao/007/y5600e/y5600e01.pdf [6 July 2005]
2. Craig, S. and L.A. Helfrich, 2002. Understanding Fish Nutrition, Feeds and Feeding. Virginia Polytechnic Institute and State University. Publication No. 420-256

3. Southgate, P., 2003. Feeds and Feed Production. In: Lucas, J.S. and P.C. Southgate, (Eds.), Aquaculture: Farming Aquatic Animals and Plants. Blackwell Publishing, Oxford, England, pp: 172198

4. Ogunkoya, A.E., G.I. Page, M.A. Adewolu and D.P. Bureau, 2006. Dietary incorporation of soybean meal and exogenous enzyme cocktail can affect physical characteristics of faecal material egested by rainbow trout (Oncorhynchus mykiss). Aquaculture, 254: 466-475

5. De Silva, S.S. and T.A. Anderson, 1995. Fish Nutrition in Aquaculture. Chapman and Hall, London, England 
6. APHA., 1998. Standard Methods for the Examination of Water and Wastewater 20th Edn., American Public Health Association, American Water Works Association and Water Environment Federation, Washington, DC

7. ASA., 1982. Methods of Soil Analysis. Part 2: Chemical and Microbiological Properties 2nd Edn., American Society of Agronomy, Inc. and Soil Science Society of America, Inc., Madison, Wisconsin.

8. AOAC., 2000. Official Methods of Analysis of AOAC International 17th Edn. The Association of Official Analytical Chemists, Gaithersburg, Maryland

9. Gloger, K.C., J.E. Rakocy, J.B. Cotner, D.S. Bailey, W.M. Cole and K.A. Shultz, 1995. Contribution of Lettuce to Wastewater Treatment Capacity of Raft Hydroponics in a Closed Recirculating Fish Culture System. In: Aquacultural Engineering and WasteManagement. Timmons, M.B. (Ed.), Proceedings from the Aquaculture Expo VIII and Aquaculture in the Mid-Atlantic Conference, Washington, DC, 24-28 June 1995, pp: 272-301

10. Lopez-Cantarero, I., J.M. Ruiz, J. Hernandez and L. Romero, 1997. Nitrogen metabolism and yield response to increases in nitrogen-phosphorus fertilization: improvement in greenhouse cultivation of eggplant (Solanum melongena $\mathrm{Cv}$. Bonica). J. Agric. Food Chem., 45: 4227-4231

11. Serna, M.D., R. Borras, F. Legaz and E. PrimoMillo, 1992. The influence of nitrogen concentration and ammonium/nitrate ratio on $\mathrm{N}$ uptake, mineral composition and yield of citrus. Plant and Soil, 147: 13-23.

12. Clarkson, R. and S.D. Lane, 1991. Use of a smallscale nutrient-film hydroponic technique to reduce mineral accumulation in aquarium water. Aquaculture Fish. Manage., 22: 37-45

13. Kamal, M. and A.E. Ghaly, 2002. Effectiveness of phytoremediation for treatment and recycling of aquaculture wastewater. ASAE Annual International Meeting, Chicago, Illinois. 28-31 July

14. MacKenzie, C.A., 1990. Purification of partially treated dairy manure through the intensive production of forage crops. MASc. Thesis, Technical University of Nova Scotia, Halifax, Nova Scotia

15. Pettersen, B.W., 1987. Ability of lettuce, rye grass and barley to reduce the nutrient salt content of wastewater from fish farming. Water Sci. Technol., 19: 129-138

16. Nelson, E.B., 2004. Microbial dynamic and interactions in the sphermosphere. Ann. Rev. Phytopathol., 42: 271-309
17. Bewley, J.D. and M. Black, 1985. Seeds: Physiology of Development and Germination. Plemum Press, New York, NY

18. Barber, D.A. and J.K. Martin, 1976. The release of organic substances by cereal roots into soil. New Phytologist, 76: 69-80

19. Ghaly, A.E., M. Kamal and N.S. Mahmoud, 2005. Phytoremediation of aquaculture wastewater for water recycling and production of fish feed. Environ. Int., 31: 1-13

20. FAO., 1987. The Nutrition and Feeding of Farmed Fish and Shrimp-A Training Manual. Food and Agriculture Organization of the United Nations, Brasilia, Brazil

21. Poxton, M.G. and S.B. Allouse, 1982. Water quality criteria for marine fisheries. Aquacultural Eng., 1: 153-191

22. Royes, J.B. and F. Chapman, 2003. Preparing Your Own Fish Feeds. Institute of Food and Agricultural Sciences, University of Florida. [online]. Available: http://edis.ifas.ufl.edu/FA097 [13 January 2006]

23. Lall, S.P., 2002. The Minerals. In: Fish Nutrition. Halver, J.E. and R.W. Hardy (Eds.), Academic Press, New York, New York, pp: 259-308

24. FAO., 1980. Fish Feed Technology. Food and Agriculture Organization of the United Nations, Rome, Italy

25. Maugle, P.D. and H.G. Ketola, 2002. Fish Nutrition and Feeds. In: Recirculating Aquaculture Systems, Cayuga Aqua Ventures, Ithaca, Timmons, M.B., J.M. Ebeling, F.W. Wheaton, S.T. Summerfelt and B.J. Vinci (Eds.), NY., pp: 505561

26. Niesar, M., R. Arlinghaus, B. Rennert and T. Mehner, 2004. Coupling insights from a carp, Cyprinus carpio, angler survey with feeding experiments to evaluate composition, quality and phosphorus input of groundbait in coarse fishing. Fish. Manage. Ecol., 11: 225-235

27. Wu, Y.V., R.R. Rosati, D.J. Sessa and P.B. Brown, 1995. Evaluation of corn gluten meal as a protein source in tilapia diets. J. Agric. Food Chem., 43: 1585-1589

28. Pereira, J.O. and E.F. Gomes, 1995. Growth of rainbow trout fed a diet supplemented with earthworms, after chemical treatment. Aquaculture Int., 3: 36-42

29. Maage, A. and K. Julshamn, 1993. Assessment of zinc status in juvenile Atlantic salmon (Salmo salar) by measurement of whole body and tissue levels of zinc. Aquaculture, 117: 179-191

30. Barrias, C. and A. Oliva-Teles, 2000. The use of locally produced fish meal and other dietary manipulation in practical diets for rainbow trout Oncorhynchus mykiss. Aquaculture Res., 31: 213218 
31. Sneath, R. and F. McIntosh, 2003. Review of hydroponic fodder production for beef cattle. Department of Primary Industries, Queensland, Australia

32. Mackowiak, C.L., L.P. Owens, C.R. Hinkle and R.O. Prince, 1989. Continuous Hydroponic Wheat Production Using a Recirculating System. NASA Biomedical Operations and Research Office, Kennedy Space Center, Florida

33. Bureau, D.P. and Y.C. Cho, 2003. An Introduction to Nutrition and Feeding of Fish. Fish Nutrition Research Laboratory, University of Guelph, Guelph, Ontario.

34. McKeehen, J.D., C.A. Mitchell, R.M. Wheeler, B. Bugbee and S.S. Nielsen, 1996. Excess nutrients in hydroponic solutions alter nutrient content of rice, wheat and potato. Adv. Space Res., 18: 73-83.

35. Jobling, M., 2001. Feed Composition and Analysis. In: Food Intake in Fish. Houlihan, D., T. Boujard and M. Jobling (Eds.), Blackwell Science Ltd., London, England, pp: 1-24.

36. Wilson, R.P., 2002. Amino Acids and Proteins. In: Fish Nutrition. Halver, J.E. and R.W. Hardy (Eds.), Academic Press, New York, NY., pp: 143-180.

37. Ayuso, M., T. Hernfindez, C. Garcia and J.A. Pascual, 1996. T. Stimulation of barley growth and nutrient absorption by humic substances originating from various organic materials. Bioresour. Technol., 57: 251-257.

38. Sargent, J.R., D.R. Tocher and J.G. Bell, 2002. The Lipids. In: Fish Nutrition. Halver, J.E. and R.W. Hardy (Eds.), Academic Press, New York, NY., pp: 181-257.

39. Watanabe, T., V. Kiron and S. Satoh, 1997. Trace minerals in fish nutrition. Aquaculture, 151: 185207.

40. Pelletier, D. and M. Besner, 1992. The effects of salty diets and gradual transfer to sea water on osmotic adaptation, gill $\mathrm{Na}^{+} / \mathrm{K}^{+}$-ATPase activation and survival of brood charr, Salvelinus fontinalis, Mitchill. J. Fish Biol., 41: 791-803.

41. Salman, N.A. and F.B. Eddy, 1988. Effect of dietary sodium chloride, on growth, food intake and conversion efficiency in rainbow trout (Salmo gairdneri, Richardson). Aquaculture, 70: 131-144.

42. Staurnes, M. and B. Finstad, 2000. The effects of dietary $\mathrm{NaCl}$ supplement on hypo-osmoregulatory ability and sea water performance of Arctic charr (Salvelinus alpinus L.) smolts. Aquaculture Res., 31: 737-743.
43. Steinberg, S.L., D.W. Ming, K.E. Henderson, C. Carrier, J.E. Gruener, D.J. Barta and D.L. Henninger, 2000. Wheat response to differences in water and nutritional status between zeoponic and hydroponic growth systems. Agron. J., 92: 353-360.

44. Kaushik, A., B.R. Kadyan and C.P. Kaushik, 1996. Sugarmill effluent effects on growth, photosynthetic pigments and nutrient uptake in wheat seedlings in aqueous vs. soil medium. Water, Air, and Soil Pollution, 87: 39-46.

45. Yueming, D.-L., S. Wu, M.W.A. Verstegen, J.W. Schrama and J.A.J. Verreth, 2001. The impact of changing dietary $\mathrm{Na} / \mathrm{K}$ ratios on growth and nutrient utilisation in juvenile African catfish, Clarias gariepinus. Aquaculture, 198: 293-305.

46. Shiau, S.-Y. and J.-F. Hsieh, 2001. Quantifying the dietary potassium requirement of juvenile hybrid tilapia (Oreochromis niloticus $\times O$. aureus). Br. J. Nutr., 85: 213-218.

47. Zhu, C.B., S.L. Dong, F. Wang and H.H. Zhang, 2006. Effects of seawater potassium concentration on the dietary potassium requirement of Litopenaeus vannamei. Aquaculture, 258: 543-550.

48. Clearwater, S.J., A.M. Farag and J.S. Meyer, 2002. Bioavailability and toxicity of dietborne copper and zinc to fish. Comparative Biochem. Physiol. Part C, 132: 269-313.

49. Eckhert, C.D., 1998. Boron stimulates embryonic trout growth. J. Nutr., 128: 2488-2493.

50. Rowe, R.I. and C.D. Eckhert, 1999. Boron is required for zebrafish embryogenesis. J. Exp. Biol., 202: 1649-1654.

51. Berntssen, M.H.G., A.K. Lundebye and A. Maage, 1999. Effects of elevated dietary copper concentrations on growth, feed utilisation and nutritional status of Atlantic salmon (Salmo salar L.) fry. Aquaculture, 174: 167-181.

52. Berntssen, M.H.G., K. Hylland, S.E. Wendelaar Bonga and A. Maage, 1999. Toxic levels of dietary copper in Atlantic salmon (Salmo salar L.) parr. Aquatic Toxicol., 46: 87-99.

53. Lorentzen, M., A. Maage and K. Julshamn, 1998. Supplementing copper to a fish meal based diet fed to Atlantic salmon parr affects liver copper and selenium concentrations. Aquaculture Nutr., 4: 6772.

54. Lanno, R.P., S.J. Slinger and J.W. Hilton, 1985. Maximum tolerable and toxicity levels of dietary copper in rainbow trout (Salmo gairdneri Richardson). Aquaculture, 49: 257-268. 
55. Baker, R.T.M. and P. Martin, 1997. Ingestion of sub-lethal levels of iron sulphate by African catfish affects growth and tissue lipid peroxidation. Aquatic Toxicol., 40: 51-61.

56. Shiau, S.Y. and L.W. Su, 2003. Ferric citrate is half as effective as ferrous sulfate in meeting the iron requirement of juvenile tilapia, Oreochromis niloticus $\times$ O. aureus. J. Nutr., 133: 483-488.

57. Lim, C. and P.H. Klesius, 2001. Growth response and resistance to Edwardsiella ictaluri challenge of channel catfish Ictalurus punctatus fed practical diets supplemented with various levels of iron. Aquaculture: Book of Abstracts, pp: 376.

58. Lin, Y.H. and S.Y. Shiau, 2005. Dietary selenium requirements of juvenile grouper, Epinephelus malabaricus. Aquaculture, 250: 356-363.

59. Hicks, B.D., J.W. Hilton and H.W. Ferguson, 1984. Influence of dietary selenium on the occurrence of nephrocalcinosis in the rainbow trout, Salmo gairdneri Richardson. J. Fish Dis., 7: 379-389.
60. Julshamn, K., K. Sandnes, O. Lie and R. Waagboe, 1990. Effects of dietary selenium supplementation on growth, blood chemistry and trace element levels in serum and liver of adult Atlantic salmon (Salmo salar). Fiskeridirektoratet. Skrifter. Serie Ernaering, 3: 47-58.

61. Jeng, S.S. and L.T. Sun, 1981. Effects of dietary zinc levels on zinc concentrations in tissues of common carp. J. Nutr., 111: 134-140.

62. Eid, A.E. and S.I. Ghonim, 1994. Dietary zinc requirement of fingerling Oreochromis niloticus. Aquaculture, 119: 259-264.

63. Sun, L.T. and S.S. Jeng, 1999. Accumulation of zinc from diet and its release in common carp. Fish Physiol. Biochem., 20: 313-324. 